\title{
On-line HPLC analysis of the antioxidant activity of phenolic compounds in brewed, paper-filtered coffee
}

\author{
Angélique Stalmach¹, William Mullen', Chifumi Nagai ${ }^{2}$ and Alan Crozier ${ }^{1 *}$
}

${ }^{1}$ Plant Products and Human Nutrition Group, Graham Kerr Building, Division of Biochemistry and Molecular Biology, Institute of Biomedical and Life Sciences, University of Glasgow, G12 8QQ, Scotland, UK; ${ }^{2}$ Hawaii Agriculture Research Center, 99-193 Aiea Heights Drive, Aiea, Hawaii 96701, USA. *Corresponding author: a.crozier@bio.gla.ac.uk

Caffeoyl-, feruloyl- and dicaffeoylquinic acids (chlorogenic acids) in infusions from green and medium roasted coffee beans were identified and quantified by reverse phase HPLC with photodiode array and $\mathrm{MS}^{3}$ detection prior to assessment of the antioxidant activity using an HPLC system with post-column on-line antioxidant detection based on 2,2'-azinobis-3ethylbenzothiazoline-6-sulphonic acid radical scavenging activity. Caffeoylquinic acids were the most abundant antioxidants and roasting induced isomerisation with a decline in 5-O-caffeoylquinic acid and concomitant increases in the 3- and 4-Oderivatives. This did not affect the level of caffeoylquinic acid-derived antioxidant activity in the roasted coffee. Roasting did, however, result in the appearance of additional unidentified HPLC peaks with antioxidant activity. Because of this and an increase in the antioxidant activity of components that did not elute from the reversed phase HPLC column, the antioxidant capacity of the beverage derived from medium roast beans was double that of the unroasted coffee. The antioxidant activity of coffees that have undergone different degrees of roasting would, therefore, appear to be due to combinations of different components. The effect of roasting on chlorogenic acids in coffee beans is considered, and the possible contribution of Maillard reaction products to the antioxidant capacity of roasted coffees is discussed.

Key words: Coffea, $\mathrm{ABTS}^{+}$, chlorogenic acids, hydroxycinnamates, HPLC-MS ${ }^{\mathrm{n}}$.

Análise por HPLC "on-line" da atividade antioxidante de compostos fenólicos em café preparado por infusão e filtrado em papel: Ácidos cafeoil-, feruloil- e dicafeoilquínicos (ácidos clorogênicos) em infusões de sementes de café verde e sementes medianamente torradas foram identificados e quantificados por cromatografia líquida de alta eficiência (HPLC) em fase reversa com detecção em fotodiodo e $\mathrm{MS}^{3}$, antes da avaliação da atividade antioxidante usando um sistema HPLC com detecção antioxidante "on-line", baseada na eliminação de radicais pelo ácido 2,2'-azinobis-3-etilbenzotiazolina-6sulfônico. Ácidos cafeoilquínicos foram os mais abundantes antioxidantes e a torração induziu a isomerização, com declínio do ácido 5-O-cafoilquínico e concomitante aumento dos derivados 3- e 4-O-cafeoilquínicos. Isto não afetou o nível da atividade antioxidante derivada de ácidos cafeoilquínicos no café torrado. Torração, no entanto, resultou no aparecimento de picos adicionais nas corridas cromatográficas, com atividade antioxidante. Por causa disto e de um aumento na atividade antioxidante dos componentes que não eluíram da coluna cromatográfica de fase reversa da HPLC, a capacidade antioxidante da bebida preparada de grãos de café medianamente torrados foi o dobro daquela de grãos não torrados, verdes. Portanto, a atividade antioxidante de cafés que tenham sofrido diferentes graus de torração parece ser devido a combinações de diferentes componentes. O efeito da torração sobre os ácidos clorogênicos nas sementes de café é discutido, assim como as possíveis contribuições de produtos da reação de Maillard para a capacidade antioxidante do café torrado.

Palavras-chave: Coffea, $\mathrm{ABTS}^{+}$, ácidos clorogênicos, hidroxicinamatos, HPLC-MS .

\section{INTRODUCTION}

Coffee, one of the most popular beverages in the world, is the subject of many conflicting reports of its effects on health. When coffee is prepared by extended boiling, and the beverage is not filtered through paper or a bed of coffee grounds, the terpenoids, cafestol, kaweol and 16-O-methyl cafestol (figure 1), which occur as fatty acid esters, enter the brew (Speer and Kölling-Speer, 2001). These substances are responsible for the reversible elevation in plasma LDL cholesterol observed in some populations, notably 


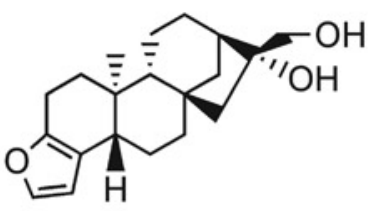

Cafestol

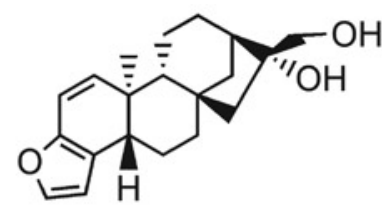

Kahweol

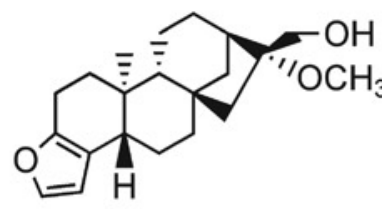

16-O-Methyl cafestol

Figure 1.Cafestol, kahweol and 16-O-methyl cafestol occur as fatty acyl esters in unfiltered coffee, consumption of which can result in elevated plasma LDL cholesterol.

Scandinavia and Italy (Urgert et al., 1996,1997; Urgert and Katan, 1997). High consumption of boiled, unfiltered coffee in some randomised trials has also been linked to increased levels of homocysteine (Urgert et al., 2000; Verhoef et al., 2002) which, along with increased cholesterol, is a known risk factor for cardiovascular disease. In vitro studies have shown that freshly brewed and instant coffee can induce mutagenic cytotoxic effects (Nagao et al., 1986; Itagaki et al., 1992) due to the gradual formation of hydrogen peroxide in the beverage (Stadler et al., 1994). Hydrogen peroxide is a reactive oxygen species capable of damaging biological molecules and membranes (Shah and Channon, 2004). However, the toxicity was assessed in vitro and it does not necessarily follow that coffee has similar effects in vivo. In keeping with this view, Natella et al. (2002) observed a significant increase $(5.5 \%, P<0.05)$ in plasma antioxidant activity in human volunteers following a single intake of brewed coffee, suggesting that coffee possesses in vivo antioxidant properties.

Coffee contains chlorogenic acids with the amounts varying between green and roasted beans (Clifford, 1998, 1999, 2000). Chlorogenic acids are a family of esters formed between certain hydroxycinnamates and quinic acid, and comprise a number of sub-groups amongst which the most widespread are caffeoylquinic acids, feruloylquinic acids and $p$-coumaroylquinic acids. The major component in coffee is 5-O-caffeoylquinic acid and its structure, together with those of other main chlorogenic acids occurring in coffee, is illustrated in figure 2.

Using a LDL oxidation assay, Richelle et al. (2001) demonstrated that phenolic compounds in coffee possessed antioxidant activity, the levels of which varied depending upon the source of the coffee beans and the degree of roasting. Other investigators have reported that 5-Ocaffeoylquinic acid has anticarcinogenic properties (Huang et al., 1988; Tanaga et al., 1993) and a protective role against LDL cholesterol oxidation in an ex vivo animal model
(Castelluccio et al., 1995). 5-O-Caffeoylquinic acid and other hydroxycinnamates also exhibit a protective effect against the oxidation of human LDL particles in vitro (Meyer et al., 1998; Moon and Terao, 1998; Morton et al., 2000; Andreasen et al., 2001), a process recognised to play a role in the formation of atherosclerotic plaques and the onset of cardiovascular disease (Mann, 2000). Cardiovascular-related conditions have a high prevalence and comprised one-third of all global deaths in 2001 (WHO, 2003). The potential health benefits related to the consumption of coffee, which is especially rich in chlorogenic acids, may therefore have implications for public health as protection against free radical damage occurring in vivo which may contribute to a decreased risk of coronary heart disease (Mann, 2000).

\section{MATERIAL AND METHODS}

Chemicals: Standard solution of 5-O-caffeoylquinic acid was obtained from AASC Chemicals (Southampton, UK). HPLC-grade methanol, acetonitrile and formic acid were supplied by Rathburn Chemicals (Walkerburn, Scotland, UK). 6-hydroxy-2,5,7,8-tetramethylchroman-2-carboxylic acid (Trolox) and the di-ammonium salt of 2,2'-azinobis3-ethylbenzothiazoline-6-sulphonic acid (ABTS) were obtained from Sigma (Poole, Dorset, UK).

Coffees: The two coffee samples (Coffea arabica) were supplied by the Hawaii Agriculture Research Center (Aiea, Oahu, USA). The coffee cherries (fruits) were harvested in November 2004 at the experimental station at Kunai, Oahu. The beans were subjected to wet processing, $16 \mathrm{~h}$ at 26$29^{\circ} \mathrm{C}$, which involved an initial fermentation of the freshly harvested cherries to remove the surrounding mucilage. The beans were subsequently dried for 10 days until the moisture content dropped to $12 \%$. Parchment was removed immediately prior to roasting. Approximately half the green beans were subjected to a medium roast using a PRE-1 laboratory roaster (Probat, Emmerich, Germany.) 
Coffee brewing: The samples were prepared by grinding the beans using an electric coffee grinder (Bodum Ltd, Northampton, UK). The coffees were subsequently brewed using an electric coffee-maker (Woolworths Group Plc, London, UK). Five grams of ground coffee were brewed using $250 \mathrm{~mL}$ of distilled water, and paper-filtered. All coffees were brewed on the same day to produce a single batch from which aliquots were frozen at $-80^{\circ} \mathrm{C}$. Prior to analysis, samples were defrosted and centrifuged for $2 \mathrm{~min}$, at $4^{\circ} \mathrm{C}$ and at $8 \times 10^{3} \mathrm{~g}$, in order to allow for homogenisation of the solutions.

HPLC-diode array and $M S^{3}$ analysis: Coffee components were separated using a Surveyor gradient HPLC system comprising a photodiode array (PDA) detector scanning from 250 to $700 \mathrm{~nm}$, and an autosampler cooled to $4^{\circ} \mathrm{C}$ (Thermo Electron, Waltham, MA, USA). Separation was performed at $40^{\circ} \mathrm{C}$ using a $250 \times 4.6 \mathrm{~mm}$ i.d column containing a Synergi $4 \mu \mathrm{m}$ Polar-RP $80 \AA$ reversed phase support (Phenomenex, Torrance, CA, USA). The mobile phase was a $60-\mathrm{min}$ gradient of $5-25 \%$ acetonitrile containing $1 \%$ formic acid, eluted at $1 \mathrm{~mL} \cdot \mathrm{min}^{-1}$. The column eluent passed through the PDA detector before being directed to a Thermo Electron LCQ Deca XP mass spectrometer with an electrospray interface (ESI) operating in full scan mode (100-1000 $\mathrm{m} / \mathrm{z}$ ). Samples were analysed using a negative ionisation mode. Data obtained were analysed using Qual Browser MFC Application software version 1.3 (Thermo Electron). Chlorogenic acids were identified using the hierarchical MS fragmentation scheme of Clifford et al. (2003) and, in the absence of standards, were quantified by reference to a 5$O$-caffeoylquinic acid calibration curve obtained with PDA detection at $325 \mathrm{~nm}$.<smiles>O=C(O)CC1(O)CC(=Cc2ccc(O)c(O)c2)C(O)C(O)C(O)C1</smiles>

3-O-Caffeoylquinic acid<smiles>COc1cc(/C=C/C(=O)OC2CC(O)CC(O)(C(=O)O)CC2O)ccc1O</smiles>

\section{3-O-Feruloylquinic acid}

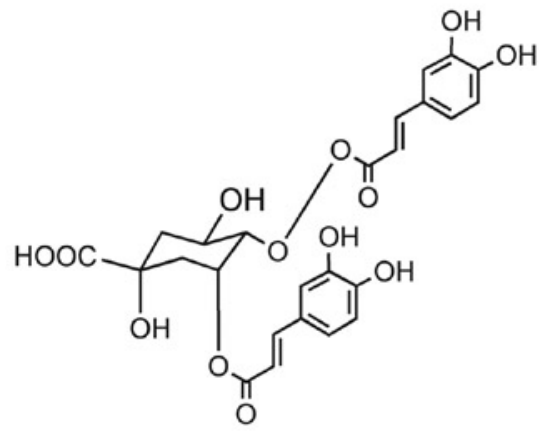

3,4-O-Dicaffeoylquinic acid<smiles>O=C(C=Cc1ccc(O)c(O)c1)OC1C(O)CC(O)(C(=O)O)CC1O</smiles>

4-O-Caffeoylquinic acid<smiles>COc1cc(C=CC(=O)OC2C(O)CC(O)(C(=O)O)CC2O)ccc1O</smiles>

4-O-Feruloylquinic acid

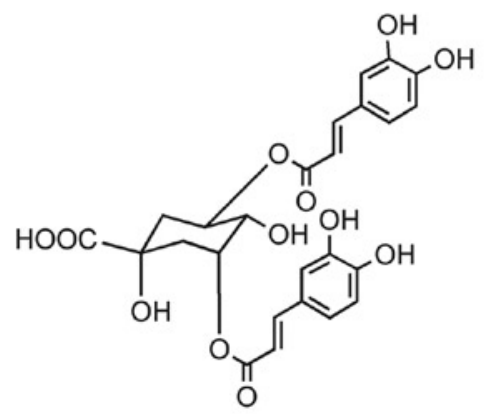

3,5-O-Dicaffeoylquinic acid<smiles>O=C(COC(O)C1CC(O)C(O)CCC1C(=O)O)c1ccc(O)c(O)c1</smiles>

5-O-Caffeoylquinic acid<smiles>COc1cc(C=CC(=O)OC2CCC(O)(C(=O)O)CC(O)C2O)ccc1O</smiles>

5-O-Feruloylquinic acid

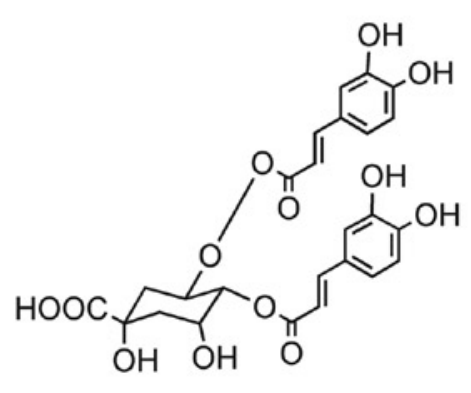

\section{4,5-O-Dicaffeoylquinic acid}

Figure 2. Major chlorogenic acids found in coffee. 
$A B T S^{+}$decolourisation assay: The antioxidant capacity of the polyphenols contained in each coffee sample was determined using an on-line HPLC system, based on the capacity of antioxidant compounds in coffee to scavenge free radicals in a solution of $\mathrm{ABTS}^{+}$(Stewart et al., 2005). A 2 mmol.L-1 ABTS $^{+}$solution containing $3.5 \mathrm{mmol}^{-1}$ potassium persulphate was prepared and incubated at room temperature overnight in darkness to allow for stabilisation of the radical. $\mathrm{ABTS}^{+}$reagent was prepared by diluting the stock 8-fold in 0.1 mol.L-1 phosphate buffer at $\mathrm{pH} 8$.

Triplicate $20 \mu \mathrm{L}$ samples of the roasted coffee sample and $10 \mu \mathrm{L}$ of the green coffee were injected into a Surveyor HPLC system and separation of compounds was carried out as described in the previous section. HPLC eluent from the PDA detector was directed to a "T"-piece, where the diluted $\mathrm{ABTS}^{+}$ reagent was added at a flow rate of $0.5 \mathrm{~mL} \cdot \mathrm{min}^{-1}$ delivered by a Shimadzu (Kyoto, Japan) LC-10 AD VP liquid chromatography pump. A Shimadzu GT-154 vacuum degasser was used to remove any oxygen in the reagent prior to mixing. After mixing by passage through a $1.5 \mathrm{~m}$ x $0.4 \mathrm{~mm}$ loop maintained at $40^{\circ} \mathrm{C}$, absorbance was monitored at $720 \mathrm{~nm}$ (Nemphlar Bioscience, Lanark, UK). Data were analysed using Thermo Electron Chromquest chromatography software.

The total antioxidant potential of each coffee was also assessed using the method described above with the coffee samples injected into the Surveyor system with the HPLC column removed. The antioxidant activities of coffee samples and individual compounds were quantified against a Trolox standard calibration curve, a water-soluble tocopherol analogue (Vinson et al., 2001). The results were defined as the concentration of Trolox equivalents in $\mu \mathrm{mol} . \mathrm{L}^{-1}$, and as Trolox equivalent antioxidant capacity values (TEAC). The TEAC measures the concentration of Trolox solution with an equivalent antioxidant potential to a standard concentration of the compound of interest.

\section{RESULTS}

Qualitative analysis of coffee: Identification of the chlorogenic acids was based on the $\mathrm{MS}^{3}$ fragmentation patterns of 18 chlorogenic acids reported by Clifford et al. (2003, 2005). The various components that were detected in the two coffees analysed in the present study are illustrated in the $A_{325 \mathrm{~nm}}$ traces in figures 3 and 4 with the mass spectral data, $\lambda_{\max }$ and HPLC retention times summarised in table 1. The main chlorogenic acids were 3-, 4-, and 5-O-caffeoylquinic acids (peaks 1, 2 and 3 respectively) with smaller amounts of 3-, 4-, and 5-O-feruloylquinic acids (peaks 4, 5 and 6 respectively) and 3,4- and 3,5-4,5-O-dicaffeoyl- quinic acids (peaks 7, 8 and 9, respectively). Mass spectral data also indicated the presence of $p$-coumaroylquinic acids and caffeoylquinic acid isomers but these compounds were extremely minor components compared to the other chlorogenic acids.

Quantitative analysis of chlorogenic acids: The concentration of the nine main chlorogenic acids in the infusions of the green and medium roasted coffee beans, based on the $\mathrm{A}_{325 \mathrm{~nm}}$ traces in figures 3 and 4 , are presented in tables 2 and 3 . The overall levels of the chlorogenic acids were not greatly different at $1130 \mu \mathrm{mol} . \mathrm{L}^{-1}$ for green coffee and $1085 \mu \mathrm{mol} . \mathrm{L}^{-1}$ for the medium roasted sample. However, roasting did bring about changes in the relative concentrations most notably a $33 \%$ decline in 5-O-caffeoylquinic acid which was accompanied by increases in 3- and 4- $O$-caffeoylquinic acids. None-theless, the 5-O-caffeoylquinic acid remained the predominant chlorogenic acid in the medium roasted beverage.

On-line HPLC-ABTS ${ }^{+}$analysis of antioxidants: Following separation of the coffee samples on the HPLC column, eluate was directed to a PDA detector and then mixed with a stabilised solution of the $\mathrm{ABTS}^{+}$radical and the solution directed to a detector monitoring absorbance at $720 \mathrm{~nm}$. The $\mathrm{ABTS}^{+}$solution has a deep blue colour, and any quenching of the radical results in a loss of colour indicated by a negative peak on the HPLC trace as illustrated in the $A_{720 \mathrm{~nm}}$ profiles in figures 3 and 4.

The traces in figures 3 and 4 demonstrate that the caffeoylquinic acids are the major contributor to the antioxidant capacity of both the green and the medium roasted coffees. However, mirroring the changes in their levels that occur during roasting, the 3 - and 4-O-caffeoylquinic acids make an increased contribution to the antioxidant activity of roasted coffee while that of 5-O-caffeoylquinic acid declined. This can be seen in the values for Trolox equivalents for these compounds presented in tables 2 and 3. These Tables also show that the total antioxidant capacity of the green coffee determined with the on-line HPLC system was $760 \pm 2.5$ $\mu \mathrm{mol} . \mathrm{L}^{-1}$ and $984 \pm 25.8 \mu \mathrm{mol} . \mathrm{L}^{-1}$ for the roasted coffee. The overall contribution of the chlorogenic acids to these figures was very similar, $760 \pm 2.5$ and $753 \pm 18.7 \mu$ mol.L $L^{-1}$ for the green and medium roasted coffees, respectively (tables 2 and 3 ). The increased total antioxidant capacity of the roasted coffee was due to the appearance of seven small unidentified peaks, designated with asterisks in the $\mathrm{A}_{720}$ trace in Figure 4, which accounted for $23 \%$ of the total antioxidant capacity of the beverage (table 4). 


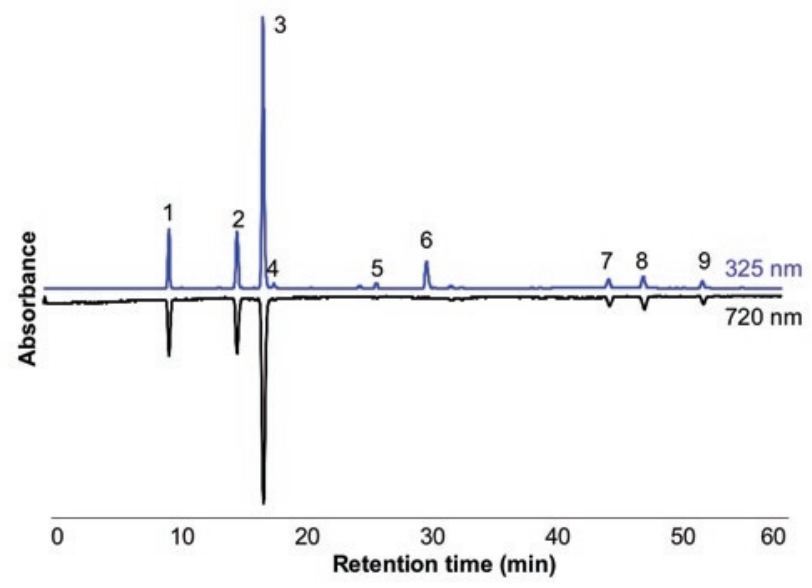

Figure 3. On-line HPLC-ABTS ${ }^{+}$analysis of coffee prepared from unroasted beans. Ten $\mu \mathrm{L}$ of coffee were analysed by gradient reverse phase HPLC with PDA detection at $325 \mathrm{~nm}$ (positive trace) prior to mixing of column eluate with $\mathrm{ABTS}^{+}$reagent and detection of antioxidant activity at $720 \mathrm{~nm}$ (negative trace). Peak 1 - 3-O-caffeoylquinic acid, peak 2 - 4-O-caffeoylquinic acid, peak 3 - 5-O-caffeoylquinic acid, peak 4 - 3-Oferuloylquinic acid, peak 5 - 4-O-feruloylquinic acid, peak 6 - 5-O-feruloylquinic acid, peak 7 - 3,4-Odicaffeoylquinic acid, peak 8 - 3,5-O-dicaffeoylquinic acid, peak $9-4,5-O$-dicaffeoylquinic acid.

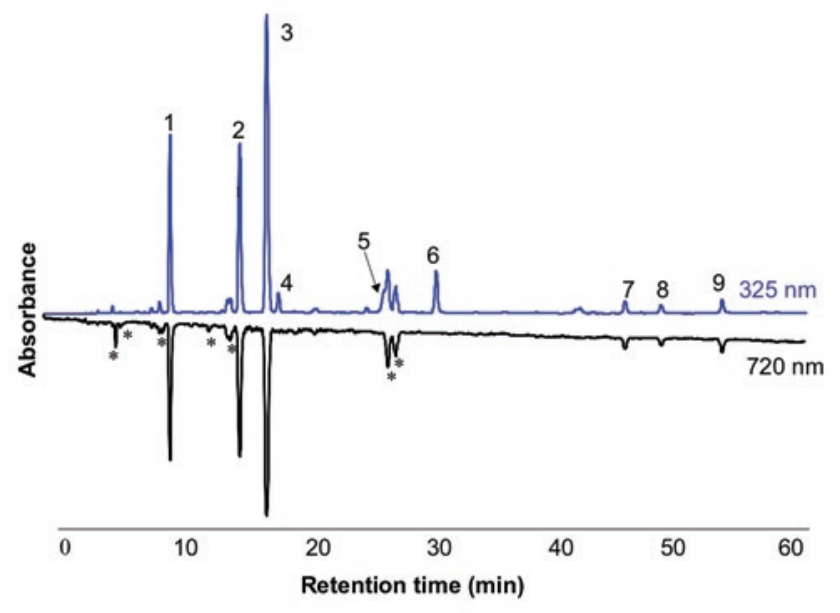

Figure 4. On-line HPLC-ABTS ${ }^{+}$analysis of coffee prepared from medium roasted beans. Twenty $\mu \mathrm{L}$ of coffee were analysed by gradient reverse phase HPLC with PDA detection at $325 \mathrm{~nm}$ (positive trace) prior to mixing of column eluate with $\mathrm{ABTS}^{+}$reagent and detection of antioxidant activity at $720 \mathrm{~nm}$ (negative trace). Peak 1 - 3-O-caffeoylquinic acid, peak 2 - 4-O-caffeoylquinic acid, peak 3 - 5-Ocaffeoylquinic acid, peak 4 - 3-O-feruloylquinic acid, peak 5 - 4- $O$-feruloylquinic acid, peak 6 - 5- $O$-feruloylquinic acid, peak 7 - 3,4-O-dicaffeoylquinic acid, peak 8 - 3,5-Odicaffeoylquinic acid, peak 9 - 4,5-O-dicaffeoylquinic acid. Unidentified antioxidant peaks indicated with an asterisk.
The TEAC values associated with the caffeoylquinic acids were very similar with 1.2 for 3 - and 4-isomers and 1.4 for 5-O-caffeoylquinic acids in both coffees (tables 2 and 3 ). Values associated with the dicaffeoylquinic acids were 1.0-1.2 for the 3,4-derivative, 1.3 for 3,5-isomer and 0.9-1.3 for 4,5-O-dicaffeoylquinic acid. This variation is due to the relatively low quantities of dicaffeoylquinic acids that were present in the coffees which resulted in the response of the online assay being near to its limit of quantification. Although present in smaller concentrations than the corresponding caffeoylquinic acids, none of the feruloylquinic acids elicited a response in the on-line $\mathrm{ABTS}^{+}$assay (tables 2 and 3). This is in keeping with earlier tests with caffeic acid and ferulic acid using the conventional $\mathrm{ABTS}^{+}$assay caffeic acid and ferulic acid indicting that methylation of the 3'-hydroxyl groups has an adverse effect on antioxidant activity (RiceEvans et al., 1997).

Total antioxidant capacity: As described above, for each coffee, the antioxidant contributions of individual HPLC peaks were added together to give the total HPLC-derived antioxidant activity. Not all compounds in a sample elute from a reversed phase HPLC column. For instance, the flavan3-ol polymers, the thearubigins, which are major constituents in black tea, fall into this category and any contribution they make to the overall antioxidant capacity cannot, therefore, be determined with the on-line HPLC-ABTS ${ }^{+}$assay system. The antioxidant activity of such components can, however, be measured by analysing samples with the on-line system but with the HPLC column removed (Stewart et al., 2005). The total antioxidant activity obtained with this method can then be compared with the corresponding value obtained by summing the antioxidant capacity of the individual HPLC peaks in order to assess the contribution of compounds retained by the column.

The data obtained by analysing samples in this way are presented in table 4 . When analysed without the HPLC column the antioxidant capacity of the unroasted coffee increased from $760 \pm 2.5$ to $1125 \pm 19 \mu$ mol.L $L^{-1}$ Trolox equivalents, an increase of $32 \%$. A more marked effect was obtained with the medium roasted coffee, with Trolox equivalents rising from $984 \pm 26$ to $2417 \pm 23 \mu \mathrm{mol} . \mathrm{L}^{-1}$, an increase of $59 \%$ (table 4 ).

\section{DISCUSSION}

Del Castillo et al. (2002) reported that progressive roasting of Arabica green coffee beans resulted in an increase 
in antioxidant activity with light and medium roasted which declined back to the level found in green beans with dark roasted coffee. In the present study, HPLC analysis revealed that the antioxidant capacity of coffee prepared from green beans was due to chlorogenic acids, with the main contributors being 5-O-caffeoylquinic acid and to a lesser degree 3- and 4-O-caffeoylquinic acids and three dicaffeoylquinic acids. Feruloylquinic acid derivatives lacked antioxidant activity (figure 3, table 2). HPLC analysis of coffee produced from medium roasted beans showed that the overall antioxidant activity of the caffeoyl- and dicaffeoylquinic acids was similar to that of the green bean beverage but the level of 5-O-caffeoylquinic acid declined while there was a concomitant increase in the concentrations of the 3- and 4-O-isomers. Roasting also resulted in the appearance of a number of unidentified HPLC components which contributed $23 \%$ of the overall antioxidant capacity (figure 4, table 3). As a result of the appearance of these compounds the antioxidant capacity of the medium roasted coffee was greater than that produced from unroasted beans at $984 \pm 26$ compared to $760 \pm 2.5 \mu$ mol.L $\mathrm{L}^{-1}$ Trolox equivalents. Both coffees contained additional compounds with antioxidant activity that did not elute from the HPLC. In the unroasted coffee these compounds were responsible

Table 1. Identification of individual compounds found in coffees, according to their retention time and their negative ionisation mass spectra. ${ }^{a}$

\begin{tabular}{|c|c|c|c|c|c|c|}
\hline Peak & Chlorogenic acids & $\mathrm{R}_{\mathrm{t}}(\min )$ & {$[\mathrm{M}-\mathrm{H}]^{-}(m / z)$} & $\mathrm{MS}^{2}$ ions $(m / z)$ & $\mathrm{MS}^{3}$ ions $(\mathrm{m} / \mathrm{z})$ & $\mathrm{MS}^{4}$ ions $(m / z)$ \\
\hline 1 & 3-O-caffeoylquinic acid & 9.0 & 353 & $\mathbf{1 9 1}, 179,135$ & $191 \rightarrow \mathbf{8 5}, 127,173$ & \\
\hline 2 & 4-O-caffeoylquinic acid & 13.6 & 353 & $\mathbf{1 7 3}, 179,135$ & $173 \rightarrow \mathbf{9 3}, 111$ & \\
\hline 3 & 5-O-caffeoylquinic acid & 15.4 & 353 & 191,179 & $191 \rightarrow \mathbf{1 2 7}, 93,85,173$ & \\
\hline 4 & 3-O-feruloylquinic acid & 16.2 & 367 & 193 & $193 \rightarrow \mathbf{1 3 4}, 149$ & \\
\hline 5 & 4-O-feruloylquinic acid & 23.6 & 367 & $\mathbf{1 7 3}, 193$ & $173 \rightarrow \mathbf{9 3}, 111$ & \\
\hline 6 & 5-O-feruloylquinic acid & 27.3 & 367 & 191 & $191 \rightarrow \mathbf{8 5}, 127,173$ & \\
\hline 7 & 3,4-O-dicaffeoylquinic acid & 41.9 & 515 & 353, 335 & $353 \rightarrow \mathbf{1 7 3}$ & $173 \rightarrow \mathbf{9 3}, 111$ \\
\hline 8 & 3,5-O-dicaffeoylquinic acid & 44.7 & 515 & 353 & $353 \rightarrow 191$ & $191 \rightarrow \mathbf{8 5}, 127,171$ \\
\hline 9 & 4,5-O-dicaffeoylquinic acid & 49.1 & 515 & 353 & $353 \rightarrow \mathbf{1 7 3}$ & $173 \rightarrow \mathbf{9 3}, 111$ \\
\hline
\end{tabular}

${ }^{a} \mathrm{R}_{\mathrm{t}}$ - retention time, $[\mathrm{M}-\mathrm{H}]^{-}$negatively charged molecular ion. Base peaks in $\mathrm{MS}^{2}$ and $\mathrm{MS}^{3}$ spectra in bold, other ions listed in order of intensity.

Table 2. Concentration and antioxidant activity of individual phenolic compounds in coffee prepared from unroasted beans.

\begin{tabular}{|c|c|c|c|c|c|}
\hline \multirow{2}{*}{$\frac{\text { Peak }}{1}$} & \multirow{2}{*}{$\begin{array}{l}\text { Compounds } \\
\text { 3-O-caffeoylquinic acid }\end{array}$} & \multirow{2}{*}{$\begin{array}{c}\begin{array}{c}\text { Concentration } \\
\left(\mu \mathrm{mol} . \mathrm{L}^{-1}\right)\end{array} \\
108 \pm 3.5\end{array}$} & \multicolumn{2}{|c|}{$\begin{array}{c}\text { Trolox equivalents } \\
\left(\mu \mathrm{mol} . \mathrm{L}^{-1}\right) \quad(\% \text { of total })\end{array}$} & TEAC $^{\mathrm{a}}$ \\
\hline & & & $90 \pm 0.2$ & 12 & 1.2 \\
\hline 2 & 4-O-caffeoylquinic acid & $134 \pm 3.7$ & $108 \pm 0.9$ & 14 & 1.2 \\
\hline \multirow[t]{2}{*}{3} & 5-O-caffeoylquinic acid & $675 \pm 14$ & $486 \pm 1.9$ & 64 & 1.4 \\
\hline & Total caffeoylquinic acids & 917 & 684 & 90 & - \\
\hline 4 & 3-O-feruloylquinic acid & $14 \pm 0.5$ & n.d. & - & - \\
\hline 5 & 4-O-feruloylquinic acid & $18 \pm 0.6$ & n.d. & - & - \\
\hline \multirow[t]{2}{*}{6} & 5-O-feruloylquinic acid & $84 \pm 1.8$ & n.d. & - & - \\
\hline & Total feruloylquinic acids & 116 & n.d. & 0 & - \\
\hline 7 & 3,4-O-dicaffeoylquinic acid & $27 \pm 0.6$ & $23 \pm 0.2$ & 3.0 & 1.2 \\
\hline 8 & 3,5-O-dicaffeoylquinic acid & $43 \pm 0.7$ & $32 \pm 0.3$ & 4.2 & 1.3 \\
\hline \multirow[t]{3}{*}{9} & 4,5-O-dicaffeoylquinic acid & $27 \pm 0.8$ & $21 \pm 0.1$ & 2.8 & 1.3 \\
\hline & Total dicaffeoylquinic acids & 97 & 76 & 10 & - \\
\hline & Total & 1130 & $760 \pm \mathbf{2 . 5}$ & 100 & - \\
\hline
\end{tabular}

a TEAC - Trolox Equivalent Antioxidant Capacity; n.d. - not detected. For peak numbers see Figure 3. Concentrations and Trolox equivalents expressed as mean values \pm standard deviation $(n=3)$. 
for $32 \%$ of the total antioxidant activity and this figure increased to $59 \%$ in the medium roasted beverage. The total antioxidant of the unroasted coffee, $1125 \pm 19.2 \mu \mathrm{mol} . \mathrm{L}^{-1}$ Trolox equivalents, was half that of its medium roasted counterpart (table 4).

Although only minor changes in chlorogenic acids were observed in the present study, the data obtained are in keeping with the findings of Del Castillo et al. (2002) who observed that roasting initially increased antioxidant activity of Arabica beans as chlorogenic acids began to decline and were replaced by low- and, to a lesser degree high molecular weight components, some of which, presumably were Maillard reaction products. Progression from medium to dark roasted beans resulted in the total antioxidant activity declining back to level detected in the unroasted beverage. The antioxidant activity of coffees that have undergone different degrees of roasting would, therefore, appear to be due to combinations of different components.

During the early roasting of beans, while there is still adequate water content, a portion of the chlorogenic acids undergo isomerisation (acyl migration) as observed in the present study with the changes in the relative amounts of the individual caffeoylquinic acids (tables 2 and 3 ). This is accompanied by some hydrolysis releasing cinnamic aids and quinic acid. Later in the roasting quinic acid epimerises and lactonises, and several chlorogenic lactones, including 3- and

Table 3. Concentration and antioxidant activity of individual phenolic compounds in coffee prepared from medium roasted beans.

\begin{tabular}{|c|c|c|c|c|c|}
\hline Peak & Compounds & $\begin{array}{l}\text { Concentration } \\
\left(\mu \mathrm{mol} . \mathrm{L}^{-1}\right)\end{array}$ & \multicolumn{2}{|c|}{$\begin{array}{c}\text { Trolox equivalents } \\
(\mu \mathrm{mol.L}-1) \quad(\% \text { of total })\end{array}$} & TEAC $^{\mathrm{a}}$ \\
\hline 1 & 3-O-caffeoylquinic acid & $191 \pm 1.0$ & $164 \pm 4.3$ & 17 & 1.2 \\
\hline 2 & 4-O-caffeoylquinic acid & $234 \pm 0.3$ & $192 \pm 3.0$ & 20 & 1.2 \\
\hline \multirow[t]{2}{*}{3} & 5-O-caffeoylquinic acid & $453 \pm 6.6$ & $335 \pm 13$ & 34 & 1.4 \\
\hline & Total caffeoylquinic acids & 878 & 691 & 71 & - \\
\hline 4 & 3-O-feruloylquinic acid & $33 \pm 0.5$ & n.d. & - & - \\
\hline 5 & 4-O-feruloylquinic acid & $36 \pm 1.4$ & n.d. & - & - \\
\hline \multirow[t]{2}{*}{6} & 5-O-feruloylquinic acid & $74 \pm 0.4$ & n.d. & - & - \\
\hline & Total feruloylquinic acids & 143 & n.d. & 0 & - \\
\hline 7 & 3,4-O-dicaffeoylquinic acid & $22 \pm 1.1$ & $21 \pm 1.7$ & 2.1 & 1.0 \\
\hline 8 & 3,5-O-dicaffeoylquinic acid & $16 \pm 0.7$ & $12 \pm 0.8$ & 1.2 & 1.3 \\
\hline \multirow[t]{3}{*}{9} & 4,5-O-dicaffeoylquinic acid & $26 \pm 0.7$ & $29 \pm 2.3$ & 2.9 & 0.9 \\
\hline & Total dicaffeoylquinic acids & 64 & 62 & 6 & - \\
\hline & Total chlorogenic acids & 1085 & 753 & 77 & - \\
\hline \multirow[t]{2}{*}{-} & Total unidentified antioxidant peaks & - & $231 \pm 2.2$ & 23 & - \\
\hline & Total & - & $984 \pm 26$ & 100 & \\
\hline
\end{tabular}

${ }^{a}$ TEAC - Trolox Equivalent Antioxidant Capacity; n.d. - not detected. For peak numbers and unidentified antioxidant peaks see Figure 4. Concentrations and Trolox equivalents expressed as mean values \pm standard deviation $(n=3)$.

Table 4. Total antioxidant capacity of coffee produced from green and medium roasted beans. ${ }^{\text {a }}$

\begin{tabular}{lcc}
\hline & & Trolox equivalents \\
\cline { 2 - 3 } & Green coffee & Medium roasted coffee \\
\hline Total antioxidant capacity & $1125 \pm 19.2(100 \%)$ & $2417 \pm 23.5(100 \%)$ \\
HPLC-derived antioxidant capacity & $760 \pm 2.5(68 \%)$ & $984 \pm 25.8(41 \%)$ \\
Difference & $365(32 \%)$ & $1433(59 \%)$ \\
\hline
\end{tabular}

a Trolox equivalents expressed as mean values in $\mu$ mol. $\mathrm{L}^{-1} \pm$ standard deviation $(n=3)$. Figures in italicised parentheses represent data expressed as a percentage of the figure for total antioxidant capacity 
<smiles>O=C(/C=C/c1ccc(O)c(O)c1)OC1CC2(O)CC(=O)C(O2)C1O</smiles>

3-O-Caffeoyl-1,5-quinide<smiles>O=C(/C=C/c1ccc(O)c(O)c1)OC1C(O)CC2(O)CC1OC2=O</smiles>

4-O-Caffeoyl-1,5-quinide<smiles>CC1C[C@H](c2ccc(O)c(O)c2)c2cc(O)c(O)cc21</smiles>

\section{1,3-trans-Tetrahydroxyphenylindan}<smiles>CC1C[C@H](c2ccc(O)c(O)c2)c2cc(O)c(O)cc21</smiles>

\section{1,3-cis-Tetrahydroxyphenylindan}

Figure 5. During roasting some of the chlorogenic acids are transformed resulting in the appearance of lactones (caffeoyl quinides) and phenylindans.

4-O-caffeoyl-1,5-quinide (figure 5), also form (Scholz and Maier, 1990; Bennat et al., 1994; Schrader et al., 1996; Farah et al., 2005). The cinnamic acids may be decarboxylated and transformed to a number of simple phenols and range of phenylindans probably via decarboxylation and cyclisation of the vinylcatechol intermediate (Stadler et al., 1996). Two of these rather unstable compounds (figure 5) have been found in roasted and instant coffee at $10-15 \mathrm{mg} / \mathrm{kg}$. To what degree these compounds, together with the plethora of volatile components present at concentrations ranging from $\mu \mathrm{g} \cdot \mathrm{kg}^{-1}$ to $\mathrm{mg} \cdot \mathrm{kg}^{-1}$, contribute to the antioxidant activity of various coffees remains to be determined. There are, however, several reports of antioxidant activities associated with Maillard reaction products such as pyrroles and furans generated in roasted coffees (Nicoli et al., 1997; Fuster et al., 2000; Yanagimoto et al., 2002, 2004).

Finally it should be noted that despite their progressive destruction during roasting, substantial amounts of chlorogenic acids survive to be extracted into domestic brews and instant coffee and for many consumers the beverage must be major dietary source of not only chlorogenic acids but also other antioxidants (Clifford, 1998).

Acknowledgements: We thank Shawn Steiman, (College of Tropical Agriculture and Human Resources, University of Hawaii) for roasting the coffee beans used in this study.

\section{REFERENCES}

Andreasen MF, Landbo AK, Christensen LP, Hansen Å, Meyer AS (2001) Antioxidant effects of phenolic rye (Secale cereale L.) extracts, monomeric hydroxycinnamates, and ferulic acid dehydrodimers on human low-density lipoproteins. J. Agric. Food Chem. 49:4090-4096.

Bennat C, Engelhardt UH, Kiehne A (1994) HPLC Analysis of chlorogenic acid lactones in roasted coffee. Z. Lebens.Unters. Forschung 199:17-21.

Castelluccio C, Paganga G, Melikian N, Bolwell GP, Pridham J, Sampson J, Rice-Evans C (1995) Antioxidant potential of intermediates in phenylpropanoid metabolism in higher plants. FEBS Lett. 368:188-192.

Clifford, MN (1998) The nature of chlorogenic acids - are they advantageous compounds in coffee ? In: Proceedings of ASIC Colloquium, Kenya 1997, pp. 79-91. ASIC, Paris, France.

Clifford MN (1999) Chlorogenic acids and other cinnamates: Nature, occurrence and dietary burden. J. Sci. Food Agric. 79:362-372.

Clifford MN (2000) Chlorogenic acids and other cinnamates: Nature, occurrence, dietary burden, absorption and metabolism. J. Sci. Food Agric. 80:1033-1043.

Clifford MN, Johnston KL, Knight S, Kuhnert N (2003) Hierarchical scheme for LC-MS ${ }^{n}$ identification of chlorogenic acids. J. Agric. Food Chem. 51:2900-2911.

Clifford MN, Knight S, Kuhnert N (2005) Discriminating between six isomers of dicaffeoylquinic acid by LC-MS ${ }^{\mathrm{n}}$. J. Agric. Food Chem. 53:3821-3832. 
Del Castillo MD, Ames JM, Gordon MH (2002) Effect of roasting on the antioxidant activity of coffee brews. J. Agric. Food Chem. 50:3698-3703.

Farah A, de Paulis T, Trugo LC (2005) Effect of roasting on the formation of chlorogenic acid lactones in coffee. J. Agric. Food Chem. 53:1505-1513.

Fuster MD, Mitchell AE, Ochi H, Shibamoto T (2000) Antioxidative activities of heterocyclic compounds formed in brewed coffee. J. Agric. Food Chem. 48:5600-5603.

Huang MT, Smart RC, Wong CQ, Connay AH (1988) Inhibitory effect of curcumin, chlorogenic acid, caffeic acid and ferulic acid on tumor promotion in mouse skin by $12-O$-tetradecanoylphorbol-13-acetate. Cancer Res. 48:5941-5946.

Itagaki SK, Kobayashi T, Kitagawa Y, Iwata S, Nukaya H, Tsuji K (1992) Cytotoxicity of coffee in human intestinal cells in vitro and its inhibition by peroxidase. Toxicol. In Vitro 6:417-421.

Mann J (2000) Diseases of the heart and circulation: the role of dietary factors in aetiology and management. In Garrow JS, James WPT, Ralph A (eds), Human nutrition and dietetics $10^{\text {th }}$ Edition, pp.689-714. Churchill Livingstone, Harcourt Publishers Ltd, London, The UK.

Meyer AS, Donovan JL, Pearson DA, Waterhouse AL, Frankel EN (1998) Fruit hydroxycinnamic acids inhibit human lowdensity lipoprotein oxidation in-vitro. J. Agric. Food Chem. 46:1783-1787.

Moon JH, Terao J (1998) Antioxidant activity of caffeic acid and dihydrocaffeic acid in lard and human low-density lipoprotein. J. Agric. Food Chem. 46:5062-5065.

Morton LW, Caccetta RAA, Puddey IB, Croft KD (2000) Chemistry and biological effects of dietary phenolic compounds: relevance to cardiovascular disease. Clin. Exp. Pharmacol. Physiol. 27:152-159.

Nagao M, Fujita Y, Wakabayashi K, Nukaya H, Kosuge T, Sugimura T (1986) Mutagens in coffee and other beverages. Environ. Health Perspect. 67:89-91.

Natella F, Nardini M, Giannetti I, Dattilo C, Scaccini C (2002) Coffee drinking influences plasma antioxidant capacity in humans. J. Agric. Food Chem. 50:6211-6216.

Nicoli MC, Manzocco L, Lerici CR, Anese M (1997) Antioxidant properties of coffee brews in relation to the roasting degree. Lebensm. Wiss. Technol. 30:292-297.

Rice-Evans CA, Miller NJ, Paganga G (1997) Antioxidant properties of phenolic compounds. Trends Plant Sci. 2: 152-159.

Richelle M, Tavazzi I, Offord E (2001) Comparison of the antioxidant activity of commonly consumed polyphenolic beverages (coffee, cocoa, and tea) prepared per cup serving. J. Agric. Food Chem. 49:3438-3442.

Scholz BM, Maier HG (1990) Isomers of quinic acid and quinide in roasted coffee. Z. Lebens.-Uters. Forschung 190: 132-134.

Schrader K, Kiehne A, Engelhardt UH, Maier HG (1996) Determination of chlorogenic acids with lactones in roasted coffee. J. Sci. Food. Agric. 71:392-398.
Shah AM, Channon KM (2004) Free radicals and redox signalling in cardiovascular disease. Heart 90:486-487.

Speer K, Kölling-Speer I (2001) Chemistry IC. Lipids. In Clarke RJ, Vitzthum OG (eds), Coffee: Recent Developments, pp.33-49. Blackwell Science, Oxford, The UK.

Stadler RH, Turesky RJ, Müller O, Markovic J, Leong-Morgenthaler PM (1994) The inhibitory effects of coffee on radical-mediated oxidation and mutagenicity. Mutat. Res. 308: 177-190.

Stadler RH, Welti DH, Stämpfli AA(1996) Thermal decomposition of caffeic acid in model systems. Identification of novel tetraoxygenated phenylindans isomers and their solubility in aqueous solution. J. Agric. Food Chem. 44:898-905.

Stewart AJ, Mullen W, Crozier A (2005) On-line high-performance liquid chromatography analysis of the antioxidant activity of phenolic compounds in green and black tea. Mol. Nutr. Food Res. 49:52-60.

Tanaga T, Kojima T, Kawamori T, Wang A, Suzui M, Okamoto K, Mori H (1993) Inhibition of 4-nitroquinoline-1-oxideinduced rat tongue carcinogenesis by the naturally occurring plant phenolics caffeic, ellagic, chlorogenic and ferulic acids. Carcinogenesis 14:1321-1325.

Urgert R, Meyboom S, Kuilman M (1996) Comparison of effect of cafetiere and filtered coffee on serum concentrations of liver aminotransferases and lipids: six month randomised controlled trial. Br. Med. J. 313:1362-1366.

Urgert R, Katan MB (1997) The cholesterol-raising factor from coffee beans. Ann. Rev. Nutr. 17:305-324.

Urgert R, Weusten-van der Woum MP, Hovenier R (1997) Diterpenes from coffee beans decrease serum levels of lipoprotein (a) in humans: results from four randomised controlled trials. Eur. J. Clin. Nutr. 51:431-436.

Urgert R, van Vliet T, Zock PL, Katan MB (2000) Heavy coffee consumption and plasma homocysteine: a randomised controlled trial in healthy volunteers. Am. J. Clin. Nutr. 72:1107-1110.

Verhoef P, Pasman WJ, van Vliet T, Urgert R, Katan MB (2002) Contribution of caffeine to the homocysteine-raising effect of coffee: a randomised controlled trial in humans. Am. J. Clin. Nutr. 76:1244-1248.

Vinson JA, Proch J, Bose P (2001) Determination of quantity and quality of polyphenols antioxidants in foods and beverages. In Packer L (ed), Methods in Enzymology, Vol. 335: Flavonoids and other Polyphenols, pp.103-114. Academic Press, San Diego, California, The USA.

WHO (2003) Cardiovascular disease: Prevention and control. World Health Organisation: Global strategy on diet, physical activity and health. http://www.who.int/ dietphysicalactivity/media/en/gsfs cvd.pdf

Yanagimoto K, Lee KG, Ochi H, Shibamoto T (2002) Antioxidative activity of heterocyclic compounds found in coffee volatiles produced by Maillard reaction. J. Agric. Food Chem. 50:5480-5484.

Yanagimoto K, Ochi H, Lee KG, Shibamoto T (2004) Antioxidative activities of fractions obtained from brewed coffee. J. Agric. Food Chem. 52:592-596. 